\title{
Migrants Meet Europeans
}

\author{
Published: 10 September 2018
}

The Strange Death of Europe: Immigration, Identity, Islam

Douglas Murray

Bloomsbury Press: London. 2017

352 pp.; ISBN: 978-1-4729-4224-1

Seldom have I come across a book that incited in me conflicting reactions of such intensity. They stem from Murray's reporting of facts-necessarily selective but shockingly effective; his conceptual analysis-eye-opening where it works but shallow and incomplete in other places; his conclusions-shattering mainstream platitudes and misconceptions but at times suffering from a narrowness of worldview and a dearth of historical perspective, not to mention a problematic interpretation of human security.

Throughout the book Murray frequently invokes the image of "death" for an entire continent, without ever explaining exactly what he means by it. A great opportunity would have been his closing chapter where he distinguishes between scenarios of prolonged business as usual and of abrupt change, neither of which really qualify as death without further discussion. One eminent literary precedent came from Oswald Spengler (a favourite read of my grandfather's), whose Decline of the West appeared in 1918. Spengler's view of how a civilisation dies is restricted to a portrait of primitive agrarian culture. While Murray mentions Spengler in passing (p. 209), his notions about the death of Europe obviously differ from Spengler's. He clearly regards it as a threat to human security even though his interpretation of human security always remains implicit and restricted to socio-political and economic aspects. Compared to accounts of how civilisations collapsed in the past [1-3], Murray's proposition rests entirely on the effects of mass immigration.

Left to her/his own imagination, the reader might reason that countries, federations, societies and even cultures don't just die like persons; rather they tend to morph into something else. Examples include the Hanseatic League, the Austro-Hungarian Empire, the British Empire and Commonwealth, the Communist International and the League of Nations. Similarly, cultural master narratives tend to be replaced by, or assimilated into, other narratives as part and parcel of historical change. Murray makes much of the fact that "the story has run out" for Europeans (p. 258) but he offers no ideas about possible replacement stories, or how they can change over time. Murray's vision of Europe's future portrays an increasing heterogeneity of values and traditions as a result of unrestrained immigration of peoples with very different traditions, leading to a dilution and fragmentation of what he regards as European cultural identity. Regardless of whether one might consider such a future as desirable or regrettable, I remain unconvinced why such a scenario should be referred to as death.

Murray defines European identity as a shared set of values, beliefs and traditions that arose from the continent's history, coming together in the form of a common culture and civilisation. Physically, aside from the allusion to geographic unity he offers no further suggestions about who gets to be included (p. 300), but newcomers from outside Europe are definitely excluded from his model of European identity. Unlike many British authors as well as a recent electoral majority, he unequivocally integrates the UK into 'Europe'. His interpretation of culture focuses on shared values but lacks a concise definition. His interpretation of 'civilisation' relies heavily on the preservation of buildings, particularly those of Christian significance (p. 263).

The main threat to European identity as Murrays perceives it comes from the direction of the cultural Other"antagonists of European culture and civilisation" (p. 258) who are entering Europe within the largely uncontrolled and massive stream of migrants from Muslim countries in North Africa, the Middle East and South Asia. Murray clearly considers national borders and sovereignty to play important parts in how Europe could address the challenges of mass immigration. Yet the very idea of a unified Europe is antithetical to borders - a notion that he criticises a European bureaucrat for emphasising (p. 178). Mur- 
ray does not weigh the advantages arising for Europeans from the borderless organisation (including rendering future intra-European wars highly unlikely) against the obvious disadvantage of allowing free mobility to unregistered immigrants; he merely points to the latter. He notes the many failings of national immigration policies without suggesting specific pan-European alternatives that might unify those fragmented approaches.

He observes with puzzlement the fact that many Europeans, including elected officials, when being faced with the re-introduction of border checks, react extremely traumatised. Murray dismisses their tears, evidently never having shared in the first place their passionate dreams of a unified, peaceful Europe without borders. They might regard the renewed border checks as indicating the death of a collective dream, but Murray neither shares their sentiment nor connects them to his obvious misgivings about the 'death of Europe'. For Murray, 'Europe' is clearly something different. Where Murray does show emotion is when he discusses the desecration of Christian institutions by homeless African refugees (p. 146) -a first indication of where his own ideals might lie.

\section{Failure of Governments}

One obvious strength of the book is the documentation and argument showing the failure of European governments in the face of the immigration challenge (p. 48), a failure that insightful protagonists such as chancellor Merkel have acknowledged themselves (p. 290). Murray accounts for the following manifestations of failure, invoking examples from across Europe but mainly from the UK, France, Sweden and Germany:

- Failure to recognise imminent or emerging problems in time for effective countermeasures (p. 76), in spite of glaring cognitive dissonance;

- Chronic emphasis on short-term, reflexive stop gap 'solutions' (p. 64) instead of longer-term countermeasures; acting on the assumption that "the consequences of our benevolence could be left to others" (p. 285);

- Devotion to political correctness and conformism to the norms of the time, at the cost of equitable consideration of human rights and human security for immigrants as well as Europeans;

- Neglect of the rights and dignity of women; violation of governments' duty of care when covering up sex crimes committed by immigrants, withholding them from the media, and obfuscating them with disingenuous rhetoric.

The latter manifestation of government failure seems particularly appalling; details of the Rotherham incidents and similar occurrences are described in Lautensach \& Lautensach [4]. Murray notes that in the UK not a single prosecution for female genital mutilation has been successful despite it being illegal for three decades and despite the number of victims having reached 130,000 . What can one even say to that? But what neither Murray nor the British government seem to realise is that a state does not have to be biased against Muslims in order to prosecute female genital mutilators to the full extent of the law, and with the same lack of mercy as the perpetrators showed those innocent little girls. In fact, what religion those perpetrators subscribe to is, and must be, entirely irrelevant to the case.

Murray points to the lack of official support for individual critics who placed free speech above their personal security and risked heir lives as a consequence. He shines the spotlight on shameful excesses of governmental cowardice, such as the withdrawal of Dutch citizenship from Hirsi Ali, a vocal female critic of human rights violations committed by Muslim groups in the Netherlands (p. 155). The fact that she subsequently chose the US as her home deserves some consideration, as do preventive policy options that European governments should consider to keep such failures from recurring. According to Murray, no such preventive policies are in place.

Underneath Murray's critique of governance lies a deep concern with ethics. He pre-empts charges of chauvinism by reducing the challenges to their normative bases, explicating repeatedly the ethical dilemmas between justice and mercy, between humanitarian intervention and consequentialist concerns for all parties, between powerful influences shaping public opinion and the moral priorities of their leaders -in short, he never trivialises the plight of the refugee while keeping his attention on the human rights and security of Europeans.

Ironically Murray himself inadvertently models another conceptual failure that most governments worldwide are guilty of-that of not grasping the contingencies of global ecological overshoot, of not following a sustainable vision of a common future. He appears entirely devoid of any understanding how important ecology is for assessing human security (pp. 276-277). While migration can be addressed in isolation in the short term [5], in the long term it cannot be decoupled from overpopulation [6] -and Murray is particularly critical of short-term solutions. His inattention to the drivers of population displacement and their causes guides him into visions of the future that are scientifically impossible. This fallacy mirrors the failure of most of the world's governments to perceive or address the transgressions of sustainable limits throughout the past half century-their blind pursuit of unlimited economic growth that will lead humanity into disaster.

A charge of failure implies that success would have been possible, had the governments only applied themselves more adeptly-an assumption that turns out more tenuous than Murray believes, as a look at European history can show. Even though Murray's critique is entirely justified, the problems of inadequate governance are more complex and widespread globally than he implies. Reducing the problem to a vague European sentiment of cultural "weariness" (which in my view hardly seems particularly unique to Europeans) seems neither helpful not entirely accurate. Success in this context would not necessarily mean actually 
stemming the tide, but establishing an effective Europewide consensus among governments and implementing a coherent, well-designed and consistent policy with the aim of stemming the tide. Murray implies as much but his recommendations reveal an underestimate of the strength of the sentiments that make people around the world want to leave their homelands. No wall can stand up for long against that strength, regardless of where or how that is attempted (Germany, Palestine, India, USA — the list is growing). Nor does he recognise the physical drivers that give rise to those sentiments, no better than the Kuwaiti official he quotes (p. 158) who stated that the reason why the Middle East cannot accept additional refugees is its steep cost of living. Both of them have not realised that large swaths of the Middle East have become ecologically uninhabitable, rendering them utterly dependent on imports of food and water-hence their cost. The refugees are driven by hunger, in addition to violent conflict. A Swedish MEP (p. 159) appears equally clueless, reducing those drivers to a vague notion of the world being "on fire". Along with the reader, Murray expresses his outrage at such incompetence, but he does not respond to it with an adequate measure of analysis into the source of the problems. What he does analyse are the underlying beliefs and assumptions that inform the poor performances of European governments.

Murray's analysis of the causative factors underlying poor governmental performance, misinterpretations of the signs of crisis, and self-deceptive public statements could still have reached deeper. He frequently portrays "countries" (which he equates with "nations") as culprits but never considers the influence of ideologies and the memes informing beliefs such as "historical guilt". His observation that "genetic guilt" is largely confined to people of European ancestry is factually defensible but seems somewhat contrived when the actual causes lie with underlying values. Likewise, the challenges of European governance are too complex to explain them as a problem with political correctness.

Murray presents a convincing vision of what Europe might have been (p. 294) had its governments not failed. Effective solutions to Europe's migration challenges would have depended on a clear consensus among governments, followed by consistent policies, on whether Europe should be open to everybody (answer: no), to anybody (answer: yes but only for people meeting asylant criteria), in perpetuity (answer: no). Asylant criteria would need to distinguish between people driven by bombs, by official persecution, by hunger, or by greed-not an easy task but necessary. An additional requirement that Murray neglects to mention is the question of carrying capacity limits within Europe, restraining immigration to mandatory quota [7]. A moral requirement that Murray does discuss is the weighing of mercy (for the asylum applicant) against justice (for both applicants and host societies). Murray further suggests that effective solutions should have included forceful exclusions similar to the Australian deterrent model, regionally diverse models of socio-cultural integration, frequent public discussion involving reflections on what European identity means to its citizens, and a deliberated consensus on the achievements of immigration policy. Europeans needed to prevent the possibility that "in pursuit of a 'liberal' immigration policy they might lose their liberal societies" (p. 295). In reality, not one of those requirements had been met by 2017 , as Murray documents.

\section{Deconstruction of Official Discourse}

Government spokespeople went to great lengths to establish factual excuses and justifications for permissive immigration policies that ultimately failed to bring about the stated aims, and often resulted in the opposite. Economic arguments pointed to Europe's 'aging population', labour markets not providing enough unskilled workers, projected benefits to the tax base and to pension funds. Murray refutes all those arguments effectively-even though occasionally his refutations become circular, as when he uses populist or xenophobic sentiments as logical objections against policies designed to combat those sentiments.

With equal effectiveness Murray dismisses the moral justifications put forth by officials, including the attractions of increased cultural diversity, historically naïve statements of what Jesus would have done about today's refugees ( $p$. 254), obfuscatory rhetoric that blatantly contradicts ongoing actions (p. 255), simplistic appeals to one-sided moral duties and an overwhelming inattention to the implications for future generations and their interests. For example, he attacks the official 'wait and see' policy for not addressing value differences between Muslim groups and host societies (p. 54) and causing bloodshed. Murray correctly concludes that such laissez-faire policies exacerbate harm, as evident in the victims of Islam-inspired anti-Semitism and homophobia. The blood on the streets could not speak more clearly.

Governments are not the only culprits, according to Murray. Contemporary European societies at large are influenced by dominant sentiments of "weariness", disillusionment, and an inability to address the shallowness of modernity (p. 258). Others have also noted that the displacement of European ethos by parochial populism, revived nationalism and basic disinterested apathy is likely to do much harm to the future welfare of the continent's inhabitants [8].

One error that Murray seems to share with the targets of his critique (Muslim fanatics as well as European governments) is an inattention to the global Big Picture and the global roots of the problems he discusses, namely global and regional overpopulation, demographic trends, climate change, scarcities and environmental degradation and the migration pressures resulting from them. Not once does Murray invoke physical limits such as carrying capacity, which would support his arguments in no small way. The drought of 2006-2009 displaced 1.5 million Syrians from rural regions, triggering waves of emigration [9]. In spite of 20,000 publications per year dealing with climate change, the international community has yet to commit to an effec- 
tive strategy to prevent global warming beyond $2^{\circ} \mathrm{C}$-which will set off refugee waves of such magnitudes that will make Europe's current problem look like a tourist boom. Murray makes much of literary dystopias of an 'occupied' Europe such as Jean Raspail's Le Camp des Saints (p. 115) but he ignores the massive amounts of scientific analyses of the global drivers of migration and intercultural conflict. Even though many of Murray's suggestions make sense on the surface, the fact that he arrives at them without taking into account the wider context renders them somewhat tentative at best.

An effective critique of European policies or practices must include the extra-European context. It cannot convince unless it draws on comparisons with the rest of the world at least occasionally. Murray's critique hardly meets that requirement; he merely explains the Eurocentric orientation of the book as that of a person who is, or feels, Eurocentric (p. 297) - not exactly meeting the standard of academic analysis.

\section{Critique of Islam-and of Secularism!}

Murray points to the precarious situation of 'minorities within minorities' (p. 142) to illustrate the intransigence of dogmatic Muslim leaders towards moral compromise and cultural adaptation when faced with internal critics and culturally different host environments. The example of reformminded Muslims becoming brutally persecuted by their own peers indicates the low level of tolerance and hypersensitivity to offence, substantiated by the abysmal historical track record of Muslim reformers. Leaving the Muslim faith still attracts the death penalty (p. 265), as does homosexuality. Murray fears that this might be a "foretaste of the intolerance to come" (p. 302) if unchecked immigration continues.

While officials emphasise the potential for learning that is evident in European Muslim minorities, Murray likens the proposed learning as adapting classroom proceedings to the "slowest child in the classroom" (p. 301), instead of choosing remedial instruction. His scathing critique of extremist statements given by Muslim clerics and community leaders reveals that their dominant values and beliefs are deeply antithetical to globally accepted standards of human rights, equity and dignity. A useful indicator is the extent of anti-Semitism evident in those statements and in the violence that they keep inciting among impressionable young Muslim males.

A journalist at the forefront of the critique of Muslim immigrant groups was the late Italian anti-fascist Oriana Fallaci. Her targets included politically emasculated Italians, Europeans and other Westerners as much as fundamentalist Muslims and, although he distances himself somewhat from her uncompromising and acerbic language, Murray's arguments derive much support from her writings. At one point Muslim groups in Italy charged Fallaci with "vilification of religion" (p. 146) which only spurned her on. The charge deserves deeper scrutiny because, as Murray implies throughout the book, every religion (Murray means
Islam; no other examples are named) should be evaluated for the ethical norms it perpetuates. I agree with Murray's implicit suggestion that such an evaluation should not only be freely encouraged but be recognised as a civic duty, to allow humanity to weed out religions that openly encourage violations of human rights and whose followers tend to frequently resort to violent means to settle disputes. In fact, Murray could have asserted more clearly that anybody should be free to ask what the commonalities are among those individuals who send out death threats to members of the public, to what extent they invoke religion as their motives, and which religion that may be. The moral benefits of such an analysis and of its conclusions justify that it is explicated and its political ramifications be publically discussed. That still does not amount to vilification, at least to anyone who has learned to tolerate what at face value might feel like an offence [4].

Murray's problem is that when it comes to Christianity he drops all that critical evaluation of religions and turns into a model altar boy, ignoring his own principles. Suddenly religion is again elevated to "a source of energy" for Europe (p. 209); one can guess which religion is meant. Not only is Murray's critique of religion extremely selective (meaning, reduced to the single target of Islam), he seems to forget all about it when he discusses secularism. A convincing critique of religion must stand on a secular platform. Murray, however, paints secularism not as the mainstay of European progressivism and the antithesis to exogenous religious fanaticism, but as the enemy of European culture (pp. 210-211). He regards the liberation of Irish society from the misogynistic dominance of the Catholic Church as just another symptom of the loss of Europe's "foundational story". Since the story of Genesis was reinterpreted along the secular principles of natural history, "we have still not found a way to live with them"-Bertrand Russell would turn in his grave at that! A poll by BBC Radio 1 among young people that revealed high levels of distrust towards all major organised religions was reinterpreted by Murray as reflecting anti-Muslim sentiments (p. 235). He considers secularism as not only having failed to strengthen the cultural identity of Europeans but being instrumental in its destruction (p. 259). This anti-secularism which Murray imposes on the reader seems quite reconcilable with his own religious version of humanitarianism but entirely counterproductive in the context of his otherwise convincing critique of Islam.

At several points Murray submits to the temptation of false generalisation, e.g. implying that Muslim immigrants are homogenous and single minded in their uncompromising values and ideals. At other times (e.g. p. 233), he acknowledges that the relationship between the "tiny number of religious extremists who carry out such attacks and the rest of the populations from the same background" is of utmost concern, implying that approval by the latter is not automatic. Muslim terrorism is not a mass conspiracy, not even common religious bloody-mindedness. It might be 'merely' violent sociopaths finding a culturally legitimated 
way to act out their desires. It is false generalisation that turns legitimate critique into racism or collective vilification of people (instead of dogma). Particularly blatant are Murray's generalisations about Muslim men (p. 194) where he first reifies the generalised proposition and then criticises officials for not following suit, all in the absence of evidence. His evidence supports no more than scattered examples of extreme behaviour, while he downplays the extent of moderation among the Muslim majority. Confusing "fact" with opinion (p. 213) does not help Murray's argumentation.

Another false generalisation that weakens Murray's argument occurs where he condemns the whole of European philosophy after the disastrous experience of attending a single conference of postmodern deconstructionist philosophers. One cannot convincingly criticise the inflexibility and dogmatism of Muslim clerics, or the blind confidence of communist apparatchiks, while blaming academics who deconstruct dominant ideologies for eroding Europe's moral foundation. No genuine advocate of 'European values' can portray the failure of communism's internationalist humanism as a good thing for humanity, or decry the decline of nationalism within a borderless Europe.

In Murray's defence it should be noted that the governments he criticises are also guilty of false generalisations, though in the opposite direction. While Murray's attempt to blame Islam for all the violence is clearly misguided, the official attempts to present anti-immigrant organisations as racist Nazis without addressing the reasons for their concerns are unjust and in the long term, politically imprudent. Murray is correct to point that out.

\section{Unsolved Problems}

\subsection{Coping With Migration at Large}

Ultimately, Murray remains silent on how an exploding world population could prevent itself from equilibrating across available geographical areas. The solutions he suggests are entirely internal to Europe and do not take into account how other countries around the world deal with challenges arising from mass immigration.

The 'huddled masses' ideology of the Americas referred from its inception primarily, or even exclusively, to immigrants from the European continent. America's geographic isolation enabled them to control the influx of less desirable ethnicities. The sentiments underlying such control might have been quite similar to Murray's. Other countries, such as Putin's Russia, take an even more protectionist approach to the influx of 'foreign' cultures, particularly Muslims in the case of Russia, attracting serious concerns about human rights violations. Elsewhere in the world, as in Palestine and India, walls are being erected-even though the most infamous wall came crashing down amid much fanfare in 1989.

Similarly, comparative analysis of historical precedents would have helped to add qualified nuance to Murray's conclusions. As a child I attended elementary school in
Bavaria with refugee children from Silesia and Bohemia; they spoke strange German and behaved in strange ways, but as they actually were in the majority I endeavoured to fit in, and managed. Clearly this would not have been so easy had those children been Sudanese or Bangladeshi. The sliding scale of cultural difference dominates Murray's key questions but he seldom addresses it head-on or suggests where the boundaries of political expediency might be placed. Further in the past, the emperor Claudius presented an erudite if longish justification why inhabitants of the empire's provinces should be awarded full Roman citizenship; at the time, urban populations in Britannia already included $25 \%-30 \%$ non-Britons. Claudius argued that extending citizens' rights would pacify the regions instead of antagonising ethnic groups, erase boundaries and borders and strengthen the empire-apart from its spirit having served successfully as a guiding principle since the beginnings of Roman expansion anyway. In AD 212 emperor Caracalla finally implemented Claudius' plan, probably extending the lifetime of the Roman empire by at least a century [10].

\subsection{The Future of Europe}

The entire book is clearly focused upon how Europe's future unfolds, being written in the past tense and analysing evidence accumulated over the past decade. Even so, Murray does not actually write much about the future; his chapter entitled "The End" (chapter 17) describes instead a new transition stage. His main focus lies on how failings in the status quo might jeopardise the aspirations of Europeans. He does pose the question how Europeans might react to the internationalisation of their countries. He emphasises people's use of religion in meeting their needs for tribal affiliation, but he disapproves of a polyreligious Europe. He considers the Enlightenment tradition of focusing on uncertainty and on a search for answers to be waning (p. 267), although Murray applies that observation differently to "religious" and "non-religious" people (a strange dichotomy). He points to the dangers of moral nihilism (p. 266), disillusionment and apathy which in his view Europeans are particularly afflicted with; I am not convinced of that distinction, having spent four decades among cultures on other continents. Other commentators have levelled such critiques more convincingly against globalised modernity in general, with no geographical distinctions [11]. Murray differs from them in his exclusive focus on Europe and on the spiritual grounding in the Christian faith that he believes is a unique strength of the European tradition. As a particular object of his despair Murray singles out the contemporary fine artsless so the state of contemporary European literature ( $p$. 283) - both of which receive blanket evaluations based on selected examples. He fervently hopes that Europeans will rediscover their spiritual grounding in spite of the growing internationalisation (p. 269) but he might underestimate the breadth of that challenge and overestimate the odds.

Murray's projections (chapter 19) for Europe's future distinguish between scenarios based on business as usual 
and scenarios based on abrupt political change. In keeping with his consistent neglect of global environmental change (which will terminate most 'business as usual' within the next decades) he implicitly assumes that no external factors will impose fundamentally new rules (p. 308). According to Murray, current policies with their trend towards cultural heterogeneity is likely to result in increasing political diversification within Europe, informed by various interpretations of lifeboat ethics in the face of sizeable immigrant populations and increasingly reticent host societies. Reformers on both sides will continue to risk persecution from all sides, which will polarise positions and radicalise splinter groups. European countries will be less likely to militarily intervene overseas as sizeable contingents of their own populations will oppose such plans (which from a human security perspective could be a good thing). Murray's prediction that immigrants will continue to encourage more immigration seems less likely as some precedents from overseas indicate otherwise.

Abrupt political change in Europe could easily occur when electorates tire of governmental failure and deception (p. 317). Another condition would be that the most belligerent sections on both sides keep failing to 'learn to be offended' [4]. The resulting moral backlash and political upheaval could have disastrous consequences for innocent bystanders on all sides, reducing further the range of political options for successive administrations (chapter 15). Murray seems reluctant to venture more detailed predictions. Taking into account the wider context of accelerating global change, it might be possible that immigration will no longer be at the forefront of Europe's concerns, or it might become utterly overwhelming. According to the UN and its Agenda 2030 for sustainable development [12] humanity is likely to stop growing after reaching about 10 billion in mid-century and live in peace, provided that assets are distributed equitably. Conversely, according to some critics, humanity is heading for at least a partial collapse of its civilisation, which will profoundly rearrange the survivors' security priorities.

Murray's argumentation makes effective uses of numbers; even so, he does not present quantitative data in any organised and transparent fashion. One might assume that his propositions would become more convincing with the help of scientific formats of representation. Yet the entire book contains no graphs, no tables, no equations or formal representation of numerical models. The academic reader might well wonder about his reasons. With respect to future scenarios, a more organised presentation of numerical trends could have supported some thinking about propositions on concrete threats and contingenciesclimatic warming of Mediterranean countries (Iberia, Italy, Greece) that will necessitate massive resettlements within Europe; regionally diverse solutions such as the development of resilient infrastructures in North Africa to pre-empt emigration into Europe; extreme protective measures to preserve groundwater and aquifers to prevent their further depletion and pollution; development of sustainable and safe energy supplies according to regionally available resources; worldwide, the North American ideal of individualistic self actualization will fall into disrepute and be replaced by European-style communitarianism [8].

\subsection{The Multicultural Project}

Murray makes much of official statements to the effect that policies of multiculturalism in Europe have run their course in the aftermath of the 2015 peak (pp. 104-108). As he points out, the discussions around multiculturalism have been hampered by the diversity of interpretations of the term and by a lack of clear definitions. It is therefore less than clear whether those policies actually failed (as Murray claims), or whether they were merely superseded in the wake of shifts in the power balance within governments. At any rate, a charge of outright 'failure' is difficult to uphold in the absence of a clear definition of the standard. Although he seems fully aware of the lack of clarity about the multicultural mission, he nevertheless insists on accusing it of having failed (as did chancellor Merkel).

On the other hand, the rise of anti-Islam sentiments throughout Europe, documented in numerous polls cited by Murray, could indicate that this failure might yet eventuate more completely. Phenomena such as the English Defence League and Pegida, portrayed by Murray as legitimate opposition to indiscriminate Muslim immigration, met with reverse racism and clumsy double standards by their governments, could indicate that Europe is still not prepared for the much more massive waves of immigration that are likely to happen in the future. Much of Murray's book begs the question how Europe might react to future challenges but offers no discussion on the matter. In any community or society the possibility of immoral consensus exists, raising questions about the legitimacy of democratic decision-making in a population whose values are not up to the task. That would have been an excellent problem for Murray to engage with in connection with Muslim minorities and their hosts in Europe.

A concise definition of multiculturalism as an aspirational agenda must focus on balance-including the extent to which integration is to be balanced against diversity. Obligations to give up certain traditions and dispositions and to supplant them with shared alternatives need to be balanced against each side's right to keep other traditions along with its sense of cultural identity. This must be organised as part of an open, inclusive and frank discussion process in which the safety of all participants is guaranteed. Murray notes that belatedly such discussions have been initiated in the aftermath of 2015.

As mentioned, Murray favours preservation of what he refers to as European culture over multiculturalism. Some of Murray's arguments in support of cultural protectionism deserve a closer look. In post-colonial North America and elsewhere, indigenous peoples (those that survived) have struggled for decades to have their cultures and languages officially recognised and protected by central governments, 
along with legal status and the rights to preserve them and to protect them from further amalgamation into the 'white'-dominated melting pot. The legitimacy of those efforts under the UN's indigenous human rights regime(s) is now widely recognised. It would be difficult to argue that the same rights do not apply to other cultures once they perceive a certain threat to their continued existence. Yet, not all threats are equally serious and should not receive blanket recognition a priori. As well, some traditional practices clearly do not deserve such protection when they violate present-day ethical norms concerning the rights and dignity of persons and the protection of endangered species.

Murray's concerns for protecting and preserving 'European culture' could gain some legitimacy under the UN's regime of recognising the rights of indigenous cultures. Unfortunately he makes no use of that argument. In fact, Murray's treatment of the plight of indigenous peoples amounts to what strikes me as his greatest faux pas in this book. He dismisses their concerns as many other Europeans might be forgiven to do from an uninformed, inexperienced perspective of someone who has neither done much traveling or reading or thinking on the matter-yet he blundered together an entire chapter on the subject, one that seems unworthy of this book. He not only rejects the claims of cultural genocide on conceptual grounds and ignores the harm done to generations of indigenous people, now exhaustively documented in the literature; he repeats the same tired platitudes raised by generations of apologists of colonialism. Here they are: 1. "It wasn't really that bad." 2. "Others did it, too." 3. "Victims and perpetrators are long dead." It is needless to point out that none of those excuses hold up to scrutiny. From my European perspective, I am unable to adequately estimate the insult that Murray's statements must constitute to anyone from a colonialized people, particularly his repeated suggestion that monetary restitution should suffice. What I can assess is the poor judgment, amateur ethical reasoning (especially on p. 177) and inadequate analysis that dominate the author's treatment of colonialism in chapter 10.

\subsection{Contributions of Christianity and of the Enlightenment in Shaping European Culture}

There is nothing objectionable about Murrays's arguments on the importance of discussing the aims of a policy before it is implemented and about the failure of European governments to do so. His arguments go astray when he enters the territory of religion. He makes two claims about Christianity in support of his Christian exceptionalism: that it somehow constitutes a monolithic constituent of European culture-he refers to it as "a source of energy" ( $p$. 209) - and that this circumstance is worth preserving-he portrays secularism as the enemy that "we have still not found a way to live with" (p. 211). He equates humanitarianism with liberalism without recognising the complexities and the diversity of perspectives on either side (p. 271). Contrary to Murray's claims (p. 288) -is it not conceivable that a profoundly humanitarian political leader nevertheless advocates the closing of Europe's borders to almost all refugees in order to prevent further violent confrontations on European territory?

Perhaps his aversion to complexity stems from Murray's tendency to overgeneralise, because he also ignores the heterogeneity of Christian beliefs and dogmas, the often violent struggles through which they asserted themselves regionally, and the brutal methods with which they protected and perpetuated their respective hegemony over the centuries (Europeans are not all "German-Lutheran" as stated on p.124). Since its uncompromising takeover in the late stages of Roman hegemony, non-Christian religious minorities managed to hang on in some regions, despite frequent and often ferocious persecutions, which were justified by relentlessly fundamentalist interpretations of religious dogma and Christian scripture combined with unscrupulous mercantilist power politics whenever overseas expansion seemed possible. Any attempts by colonised peoples to resist were dealt with brutal repression and often genocide, either deliberate or accidental but seldom explicitly regretted ever since. Beyond the misuse of the Christian religion for the sake of power politics (this misuse is something that presumably all organised religions suffer from), there remain some serious violations of human dignity in Christian dogma-on top of my list are the assumption of original sin and the commandment of sexual abstinence combined with widespread systemic cover-ups of the sexual abuse of children in the Catholic Church. Without meaning to single out the Christian religion, an external observer might find little ground for the exalted status Murray attributes to it and his singling out of Islam on the negative side. In short, Murray's contentions that European Christianity is monolithic and worth preserving are not nearly as self-evident as he would have it-never mind the subtle message in the cover design. On the other hand, his staunch anti-secular position alienates the enlightened reader-Richard Dawkins would have a field day with it-and weakens his attack on uncompromising fundamentalism within Islam. Someone who decries as "cultural loss" the efforts of Irish society to shake off the misogynist stranglehold of the Church (p. 212) has no authority to criticise another religion for its apparent dearth of internal critics.

One significant example goes especially far to weaken the claim of European religious homogeneity and moral superiority. It is the history of European Jewish communities. There is no need to go into the abundant evidence of chronic (i.e. not occasional) persecution of the Jewish faith, often under the thinnest of religious pretensions covering substantial robbery of economic assets, to conclude that a claim of exceptional intercultural tolerance in European tradition is tenuous at best [13]. On the other hand, the example of the European Jews shows how it is possible for a minority culture to preserve its identity and persist over millennia amidst circumstances that varied mostly between disparagement, ridicule and open hostility. So much for European tolerance. 
One might invoke as a mitigating circumstance in European history the emergence of the enlightenment as a beacon of humanist secularity, illuminating the dark realms of fundamentalist superstition after centuries of oppressive religious dogmatism. But then colonialism hit in full force, and once again European 'culture' served as an instrument of political and cultural hegemony. Even the ideals of the French revolution, as unprecedented and enlightened as they were at the time, ultimately failed to exert much liberating influence over the rest of world. Now we have the United Nations, neo-colonialism and the all-powerful New Economic Paradigm, delivering both benefits and harms to the rest of the world but clearly founded on WesternEuropean hegemony.

Only there are some pockets of resistance. Unfortunately some of those draw their strength from an equally relentless application of religious dogma, an equally blatant contempt of human rights and gender equity-and it is those objectionable characteristics that Murray attacks in his critique of Islam. It works in his favour that Islam and how it is practiced by some egregious immigrant communities in Europe in many respects make for an easy target. Its violations of human rights are much more blatant, uncompromising and racially charged as the persistent gender inequity, sexual violence, racism and wholesale ecocide practised in the modern 'West'. There is plenty of am-

\section{References and Notes}

[1] Cline EH. 1177 B.C.: The Year Civilization Collapsed. Princeton University Press; 2014. 10.1515/9781400849987.

[2] Tainter JA. Sustainability of complex societies. Futures. 1995;27(4):397-407. doi:10.1016/0016-3287(95)00016-p.

[3] Diamond J. Collapse: How societies choose to fail or succeed. London, UK: Penguin Books; 2005.

[4] Lautensach AK, , Lautensach SW. Prepare to be Offended Everywhere: How Cultural Safety In Public Places Can Prevent Violent Attacks. International Journal of Sustainable Future for Human Security. 2015;3(1):56-62. doi:10.24910/jsustain/3.1/5662.

[5] Crist E. Decoupling the global population problem from immigration issues. The Ecological Citizen. 2019;2(2):epub-016. Available from: https://www.ecologicalcitizen.net/article.php?t=decouplingglobal-population-problem-immigration-issues.

[6] Hines C. Immigration and population: The interlinked ecological crisis that dares not speak its name. The Ecological Citizen. 2018;2(1):51-55. Available from: https: //www.ecologicalcitizen.net/article.php?t=immigration-populationinterlinked-ecological-crisis-dares-not-speak-name. munition there, particularly well portrayed in chapter 8 on the controversy in the Netherlands following the assassination of the popular human rights activist Pim Fortuyn ( $p$. 137). Unfortunately Murray blows most of it on a simplistic comparison of religions. He seems to place his hopes for Europe onto some polarising effect that the Islamic influx is to have on European Christianity (such as it is), an effect of re-invigoration and (God help us) reformation that amalgamates European Christians. He implies that this would be the proper thing for Europeans to do, never mind their celebrated secular Enlightenment ideals, which surely belong to Europeans more than to most other cultures.

No book can keep the reader engaged unless it conveys a modicum of controversy. Murray has gone out of his way to stick to that principle on every page. He presents a deeply disturbing portrait of contemporary Europe in its current turmoil, which reminds of a student who fails test after test without having recourse to adequate skills and attitudes for problem-solving and planning. Regardless of the varying quality of his arguments, Murray's message deserves to be noticed.

Alexander Lautensach

School of Education, University of Northern British Columbia, Canada; E-mail: Alex.Lautensach@unbc.ca

[7] Consideration of carrying capacity might well keep highly populated Muslim countries such as Indonesia, Bangladesh and Pakistan from openly inviting Muslim refugees. This would be difficult to verify for as long as ecological arguments remain taboo in the political arena.

[8] Lesch H, Kamphausen K. Die Menschheit schafft sich ab. 6th ed. München, Germany: Verlag Komplett-Media; 2017.

[9] Data in this paragraph stem from an interview of Stefan Rahmstorf, Director of the Potsdam Institute for Climate Impact Studies (www.fixinglife.de).

[10] Beard M. SPQR: A history of ancient Rome. London, UK: Liveright; 2015.

[11] Bowers CA. Liberation pedagogy in the age of environmental crisis: The culture of denial. Albany, NY, USA: SUNY Press; 1997.

[12] Sustainable Development Goals: 17 Goals to Transform Our World. New York, NY, USA: UN Department of Public Information; 2015. Available from: https://www.un.org/sustainabledevelopment/ sustainable-development-goals/.

[13] Smith HW. The Continuities of German History: Nation, Religion and Race across the Long Nineteenth Century. Cambridge, UK: Cambridge University Press; 2008. 